\title{
NEW SERIES OF PUBLICATIONS WORKS OF EMINENT POLISH REPRESENTATIVES OF FINANCIAL LAW
}

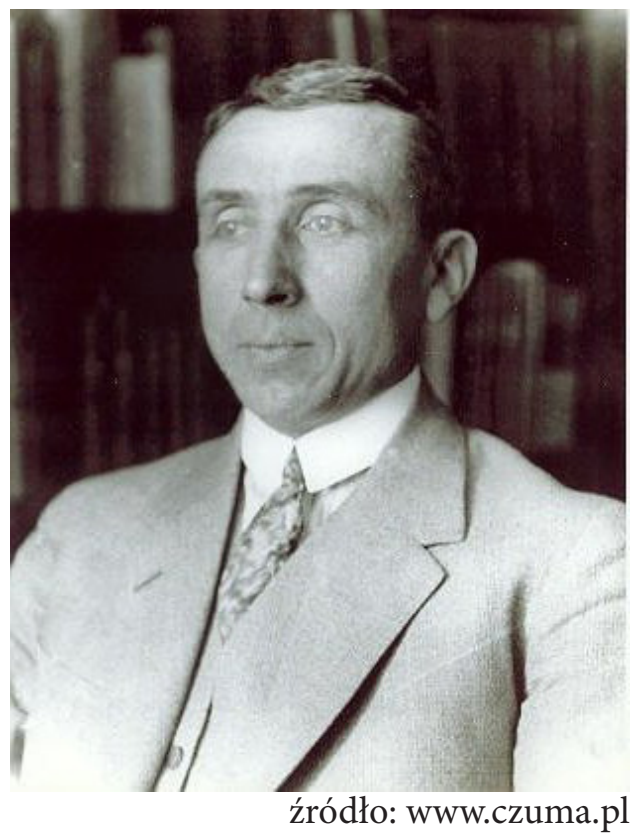

At the scientific conference held on 18-20 September 2019 in Grodno (Belarus), Prof. Marina Karasieva (Sentsova), the Chairwoman of the Program Council of the "Center for Information and Research Organization in Public Finance and Tax Law in the Countries of Central and Eastern Europe", reported the idea to publish in Russian, within the framework of the activity of the Center, works of prominent Polish representatives of financial and tax law. After a long discussion on the choice of the first work in the series, it was decided to accept the proposal of $\mathrm{dr}$ hab. Janusz Stankiewcz, i.e. the edition of the book by the outstanding Polish scholar and politician, Prof. Ignacy Czuma, entitled "The Balance of the Budget compared to the budget law of different countries". The book was published in Lublin in 1924. Dr hab. Janusz Stankiewicz also made available his copy of the above work by Prof. Ignacy Czuma for translation into Russian and publication in print. The permission for the publication of the work in the presented form (under certain conditions) was given by the sons of the scholar, Benedykt and Andrzej Czuma. On this occasion, it is worth recalling the remarkable personality of the great Polish patriot and scholar, Professor Ignacy Czuma, his life and scientific, social and political activity. Ignacy Czuma was born on 22 October 1891 in Niepołomice near Kraków, he came from a peasant family. In 1912, he started studying law at the Jagiellonian University, which was interrupted by the First World War. Between 1914 and 1915 he served in the Austro-Hungarian Army and was a Russian prisoner of war between 1915 and 1919. After his service in the Polish Army in 1920, he resumed studies at the Faculty of Law of the Jagiellonian University, which he completed in 1922 with a $\mathrm{PhD}$. In 1925, he was awarded the degree of Habilitated Doctor for the above mentioned dissertation "The Balance of the Budget compared to the budget law of different countries". In 1922, Ignacy Czuma started his professional career at the Department of Treasury and Fiscal Law at the Catholic University of Lublin, where he remained until the end of his academic career. Initially a deputy professor of fiscal science and legislation, he was promoted to associate professor in 1927 and to full professor in 1930 at the Faculty 
of Law and Socio-Economic Sciences of the Catholic University of Lublin. Between 1926 and 1928 he was the Dean of the Faculty of Law and Socio-Economic Sciences, and between 1938 and 1939 he was the Vice-Chancellor of the Catholic University of Lublin. On 11 November 1939 he was imprisoned by the Gestapo and placed in the Lublin Castle, where he remained until March 1940. Released due to the intervention of the International Red Cross, he returned to Niepołomice, where he conducted secret teaching and other forms of underground activity. In 1950, he was arrested by the Security Service and sentenced to 10 years in prison. Released in 1953 with a prohibition of professional work, he resumed it only after the political changes, being a professor at the Catholic University of Lublin in the years 1957-1960. As a social and political activist Ignacy Czuma founded and was the first president of the Polish Economic Society in Lublin, president of the Polish Western Union for Lublin and Wolyn Province, president of the Anti-Bolshevik League. In the years 1930-1935 he was a deputy to the Sejm for the Non-Partisan Block for Cooperation with the Government. He was a co-author of the first ten articles of the April Constitution (1935) and the author of the provision indicating president's responsibility before God. In 1949, he received the title of Papal Chamberlain from Pius XII. Earlier, in 1935, he was awarded the Commander's Cross of the Order of Polonia Restituta.

Ignacy Czuma is known for his numerous scientific works in the field of law, especially fiscal law and treasury, constitutional law, economics, political science, philosophy and ethics. In these works he presented a thomistic attitude based on the Catholic social doctrine and recognition of absolute justice and morality, permeating all beings and goods. In addition to the above-mentioned work "The Balance of the Budget compared to the budget law of different countries" (1924), the following works also deserve special attention: "Systemic Absolutism" (1934), "Responsibility of the President" (1932), "Systemic Basis of Treasury in the context of the April Constitution" (1937). He was a supporter of the family protection in tax law (see his work "Legal Reforms for the Family Protection") (1936). His highly critical works on the communist system and state as well as the fascist system of the Third Reich should also be noted. Ignacy Czuma died on 18 April 1963 in Lublin. 